\title{
The Effect of Service Quality and Brand Image in the Air Cargo Industry on Customer Satisfaction and Loyalty of PT Garuda Indonesia (Persero) Tbk
}

\author{
Terang Maharani ${ }^{1, *}$ Sari Wahyuni ${ }^{2}$
}

\author{
${ }^{1}$ Department of Management Universitas Indonesia, Jakarta, Indonesia \\ ${ }^{2}$ Department of Management Universitas Indonesia, Jakarta, Indonesia \\ *Corresponding author. Email: terang.dyah@gmail.com
}

\begin{abstract}
Air cargo is the only business that survived during the pandemic of Covid-19 for airline company especially Garuda Indonesia. Most of the airline companies made a new strategy related to their cargo business by forming preighters or converting their planes completely into cargo planes which further increased the competition between airlines in Indonesia. Garuda Indonesia, as the dominator of the cargo market in Indonesia, both domestically and internationally, needs to maintain its business so that it is not replaced by other airlines. As a company engaged in the service sector of delivering goods from port-to-port, improving service quality is an important aspect to increase competitive advantage and brand image is a supporting factor in sales, so this research is aimed to see the effect of service quality and brand image on customer loyalty directly and indirectly with the mediation of customer satisfaction. This study was analysed by using SEM-PLS and IPMA methods to see the relationship between the variables. It contributes to both managerial and theoretical customer behaviour through empirical data research based on surveys distributed to 118 freight forwarders in the Jabodetabek region, who cooperate with Garuda Indonesia Cargo. Through this research, it was found that there is a need for service improvement in the form of safe payment transactions and promotional products that can increase customer loyalty.
\end{abstract}

Keywords: Air Cargo, Service Quality, Brand Image, Customer Satisfaction, Customer Loyalty, SEM-PLS, IPMA.

\section{INTRODUCTION}

Amidst the sluggish aviation business due to the Covid-19 pandemic, there was one business that survived in the situation that was the cargo aviation business [1]. Based on the report of Badan Pusat Statistik Indonesia in 2020, when the domestic market for passengers dropped to $80 \%$, the cargo market decreased for less than $1 \%$ from the previous year. As a fact, the air cargo operations are considered important to help Indonesian government when transporting the specimen samples of the suspected patients of COVID19 to the capital city, Jakarta, as centralized laboratory due to the limited testing equipment in the origin. These specimens needed fast delivery to preserve its condition to minimize damage and uncontaminated culture and transported from city-to-city within hours. Thus, air cargo is the applicable solution. Not only that, due to the stay-at-home directives applied in many areas, according to Jakarta Post based on the survey on Twitter, $89 \%$ of its user migrated to online shopping starting from the first quarter of the year 2020 [2] and it was still in the early stage of the pandemic growth in Indonesia. This is a good thing for the air cargo industry as they offer transportation of goods services that require relatively short delivery times.

Air cargo is the supporting business of airlines in Indonesia. However, due to the pandemic, most of airlines found an adaptive solution to remain exist in the market by making it to their primary strategy. It was also supported by the Indonesian Government through Surat Edaran Ditjen Perhubungan Udara No. 17/2020 and IATA Guidance for the transport of cargo and mail on aircraft configured for the carriage of passengers Ed 3, $4^{\text {th }}$ May 2020 that allowed airlines to maximize its idle cabin compartment to be loaded with cargo.

Most of passenger airlines were executing this strategy to remain operational and Garuda Indonesia unexceptionally. Through receiving the order to transport medicinal, it helped the airlines not only to survive, but also gain a new perspective of the air cargo sector. They assumed that the air cargo business was 
resistant to disruption like pandemic. In the passenger's sector, Garuda Indonesia is in the second place compare to Lion Air. However, in terms of air cargo domestic, the market share is owned by Garuda Indonesia with $30 \%$ market share and Lion Air was 17\% in August 2020. This business is mostly business-to-business relationship with $80 \%$ of the customers were coming from the freight forwarders or cargo agent. They maintained this relationship with the freight forwarders trough an agreement which covered about slot, volume, price, discount, incentives and many more. When the company terminates the contract, it will have a direct impact on the financial position of the cargo airlines company.

According to McKinsey partners [3], they estimated that about one in ten firms tends to outgrow their rivals during downturns and eventual recovery. Those companies were not totally redoing the plan or putting the brakes on anything but worrying about where to step back and where to lean forward. In the last downturn, for example, the Finnish producer aggressively invested in the services sector, building it up through the recession while demand was still strong. The key concept is to remain accelerated throughout the healing period. Garuda Indonesia saw this opportunity in the cargo market that survived during the pandemic crisis. Instead of fighting the market share, Garuda should find strategies on how to retain their loyal customers since most of their revenues are coming from their maintained customers, the cargo agent or freight forwarders. On the book titled "Customer Loyalty: How to Earn It, How to Keep It", Griffin [4] mentioned about companies' paradox telling that winning the market share to gain profitability could risk the companies' most marginal customers, the loyal customers. To outperform the competitors and remain sustainable in the industry, GA Cargo should understand what factors that influence their loyal customer.

The previous studies related to customer loyalty in airlines industry largely focused on the passengers' sector. There is only little research related to customer loyalty in air cargo context. Customer loyalty study in the air cargo sector mainly relates to air cargo terminals or freight forwarders $[5,6,7,8]$.

Some scholars conclude that that consumer satisfaction is a predictor for customer loyalty [9, 10, 11]. In any campaign project, consumers are major decision-makers. They want a brand that adds value and optimizes their satisfaction. Air cargo industry are therefore searching for the most influential determinants of consumer satisfaction and loyalty. Customer satisfaction leads to loyalty that contributes to the company's economic performance in terms of profitability, market share and investment return [12]. Long-lasting customer-provider partnerships contribute to improved cross-selling, potentially higher costs, and constructive word- of-mouth (WOM) contact [13, 14]. While numerous studies have studied the relationships between service quality, brand image, consumer satisfaction, and customers loyalty in many industries in Indonesia, the customer loyalty phenomenon during the pandemic has been shown in only a limited amount of research. The impact of pandemic causes most of airlines to hit the bottom-line, reduce its manpower, massive delayed and cancelled flight which indirectly affect the service quality but taking care of customers and put their interest first can put the company's brand to lead [15]. The goal of the analyses was to determine the impacts of service quality and the brand image on consumer loyalty with the mediating impact of customer satisfaction. The data was drawn by using confirmatory analysis based on the survey distributed to 150 freight forwarders in domestic area based on the partnership with Garuda Indonesia Cargo.

\section{LITERATURE REVIEW}

\subsection{Service Quality}

The air freight business market has played a critical role in foreign economic development over the past few years, and excellent service quality is a significant factor in enhancing industrial productivity. Therefore, in a world full of intense competition, how to win market share has turned out to be a crucial problem in the industry. According to Deloitte, [16] since benefit, cost savings and market share were strongly integrated by delivering good service quality, service quality was the core driver of a profitable business in goods' repeat buying intentions. Providing the service quality to customers is a significant tool for company sustainability and give a competitive advantage. Thus, Parasuraman, Zeithaml and Berry [17] came up with their service quality model to measure the ten criteria of service: reliability, responsiveness, competence, access, courtesy, communication, credibility, security, understanding/knowing the customer, and tangibles. These criteria are then simplified into five dimensions:

(1) Tangible: physical equipment, infrastructure and efficiency of employees.

(2) Reliability: the willingness to carry out the promised operation accurately and appropriately. 
(3) Responsibility: willingness to serve customers and provide timely assistance.

(4) Assurance (including courtesy, competence, credibility and security): employee understanding and kindness and ability to cultivate client confidence and trust.

(5) Empathy (including access, communication, understanding the customer): The company offers personalized service and assistance to its customers.

\subsection{Brand Image}

Based on Berry [18], for company who sell goods, the brand is coming from the product, while for services, the company is the main brand for the product. According to Bambang Wijaya [19], brand leave a footprint on the customers' mind and hearts in a form of symbol that is meaningful. Therefore, the brand is not only represented through an emblem, slogan, trademark or product sign. Anytime a brand is introduced, they expect consumers' recognition. Brand is the initial view of a products that helps customers to recognize such goods. The brand is a commitment to give performance, rewards and supports in form of products or services to buyers or customers [19]. The attachment of customer to a brand become an important factor to manage longterm relationship with the companies [20]. Building solid brand perceptions is a high concern for several companies nowadays.

\subsection{Customer Satisfaction}

Consumer satisfaction was important since customer loyalty and profitability are closely related

[12]. Customer satisfaction reports are constructive and cost-effective. Having more consumers means that the business remains successful against its rivals. Satisfaction is a huge cause for an improvement in income as happy customers come back for another transaction [21]. Increased customer loyalty help businesses to enhance their market system or product quality.

The satisfied customers are the indicator of how a business' goods and services match or satisfy consumers' demands. It can be described as the degree to which the perceived output of the commodity meets the expectations of the purchaser [22, 23]. Satisfied customers would return after the product and service first satisfied them throughout their presence. They are bound to spread the word by telling their peers about the product or service that impressed them with aggregation and long- term customer loyalty. Therefore, more businesses spend more resources to nurture and sustain customer loyalty by rising their number of satisfied customers.

\subsection{Customer Loyalty}

Reichheld \& W. Earl Sasser [24] loyalty has a benefit for the corporation in four respects: (1) loyal customers purchase a commodity of the same sector again with an alternative option; (2) spend good amount of money; (3) market it to other new customers; and (4) offer valuable and sincere advice for enhancing product or service quality. According to Mcilroy \& Barnett [25], consumer retention is an important element in creating a customer loyalty program. Satisfaction is a crucial measurement of the degree to which customers' needs and criteria are satisfied as consumers evaluate how frequently the client is ready to repeat purchases and engage in partnership actions. Oliver [26] sees gratuitousness as dedication to the method of partnership, and can also be viewed as a profound devotion, in terms of situational surveillance and the potential marketing of swapping behavior, frequently re-buying or patronizing a desired product or service. Strong loyalty is therefore a cost-effective factor for a company and a core source of income.

\section{RESEARCH METHODOLOGY}

\subsection{Conceptual Framework and Hypothesis}

Previous analysis has shown that service quality, customer satisfaction, brand image and customer loyalty are all essential to airlines. Yet little is known about the effect of implementing the combined integration model in the Indonesian air cargo industry. We adopt the previous research related the correlations of the construct that had been done by Liat et al., [27] as the model reference of this study (Figure 1). According to the previous research [28], strong brands could withstand crises such as weakening market fortunes or upheavals of customers preferences thus we change corporate image into brand. The research assessed by Liat et al. [27] explored the variables in direct relative manners. Meanwhile, we can see the associations between variables of consumer satisfaction with service quality and brand image on the ultimately based customer loyalty indicator both explicitly and indirectly.

In this area, the research explored how service quality, brand image, and consumer retention are linked 
to customer loyalty. The theories that emerged from this case study are as follows.

H1: Brand image positively influence customer satisfaction.

$\mathrm{H} 2$ : Service quality positively influences customer satisfaction.

H3: Customer satisfaction positively influences the customer loyalty.

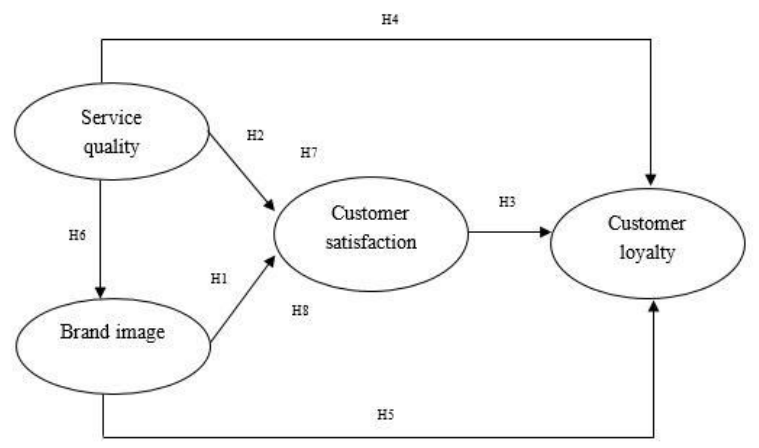

Figure 1 Conceptual Framework

H4: Service quality has a direct positive influence on customer loyalty.

H5: Brand image has a direct positive influence on customer loyalty.

H6: Service quality positively influences brand image.

H7: Service quality positively influences customer loyalty with mediating effects of customer satisfaction.

H8: Brand image positively influences customer loyalty with mediating effects of customer satisfaction.

\subsection{Research instrument}

A survey instruments were adopted from the previous study related to the variable used in this research. For the service quality, the instruments were adopted from Lee et al. and Mathong et al. [29, 30] with five dimensions of reliability, responsiveness, assurance, empathy and tangible which consists of 22 items in total. The reliability aspects tried to explore the response of data related to i.e (1) airline was providing service as promised (2) able to handle customers' problem (3) staff handling the goods without any damage (4) on time delivery services (5) issued document accurately. The responsiveness aspect consists of i.e (1) keeping customer update related to the shipment (2) prompt service to customer (3) willing to help customer if any issues (4) respond any inquiry in fast response. The assurance aspect consists of i.e (1) the security for the goods were good 2) courtesy of the employees were good (3) staff had good knowledge of expertise (4) transaction security. The empathy consists of i.e (1) attentions to their customers (2) capable of handling customers' complaint (3) providing promotional activities to customers (4) able to perform special need from customers (5) providing convenient business hours. The last is about the tangibles aspect of air cargo which consists of i.e (1) equipped with modern equipment (2) adequate routes and networks (3) adequate system for tracking (4) the employees maintained professional appearance.

Four items belonged to brand image which adopted from the previous research by Chang Liu [31] and Juga [32]. It consists of i.e (1) the perception if GA Cargo was the best brand in the industry (2) GA Cargo was good quality (3) GA Cargo had better reputation than any other brand (4) GA Cargo was recommended by many. Further about the customer satisfaction variables which consist of five indicators. It was adopted from the previous research by Juga et al. [32]; Le et al., [29]. It was reflected with questions i.e (1) providing services in a timely manner (2) if the customers were satisfied with the GA Cargo management (3) satisfied with price (4) if they thought it was the right choice to use GA Cargo services (5) overall experience was satisfying with GA Cargo. The last variable consists of five indicator that represent customer loyalty that was adopted from the previous research by Juga et al., [32]; Anselmsson et al., [33] i.e (1) recommend GA Cargo to other (2) consider GA

Cargo as the first choice (3) continued to use GA Cargo despite price increase (4) intended to use GA Cargo continually in the future (5) encouraging other colleague to use GA Cargo. The questionnaire was using the Likert five- point Likert scale started from strongly disagree to strongly agree. In order to validate the questionnaire, the pilot test was taken, and some minor changes were conducted related to the structure of the sentences in the questionnaires, however the overall findings showed enough reliability and validity of the questionnaires to continue with the data collection.

\subsection{Sample and data collection}

A sample is a part of a group or world of individuals, artefacts or cases to examine [34]. A sample should be a representation of the population. It is to be verified that the sample demonstrates the characteristics 
of the population, and that it is indicative of the general characteristics of the population. A non-probable estimation was used. The purposive form of sampling is the conscious choice to engage in a sample centred on such parameters [34]. The aim is to identify and determine about relevant individuals and categories. Bernard [35] and Spradley [36] suggested that number of participants are crucial to the legitimacy of any assessment. Purposive sampling methods focus on quantitative knowledge [34].

In this research, the role of service quality and brand image in deciding customer loyalty was investigated along with the indirect impact of customer satisfaction. In order to meet this goal, a target community of all freight agents who had been cooperating with GA Cargo over the past year was established. Minimum sample is formed by using the Slovin formula [37]. The formula is given as follows:

$\mathrm{n}=\mathrm{N} /(1+\mathrm{Ne} 2)$

notes:

$\mathrm{n}$ is the sample size

$\mathrm{N}$ is the population size

$\mathrm{e}$ is the margin of error

Total population of the respective cargo agents or freight forwarders were 150 companies, with the consideration of $95 \%$ confidence level and $5 \%$ margin of error, using Slovin's Formula, researcher found the minimum sample for the research is 109 respondents.

Data collection is important for research because it offers better understanding of theory. The forms were distributed and filled out via Google Forms since during pandemic, it was better to consider the physical contact or social distancing. Thus, the respondents were contacted via WhatsApp or by phone to inquire whether they want to take part in the survey. The respondents were not asked to have names or features for secrecy and objectivity of the questionnaires. A letter providing the intent for the analysis was appended. Respondents were required to enter their e-mail addresses if they wished to read the final report.

\subsection{Analytical Method}

Structural Equation simulation was used in this analysis. SEM is a multivariate method for market research that can investigate linear as well as other non- linear causalities [38]. Marketers evaluate the connections between variables of interest in order to distribute resources that best serve their clients. This research used the PLS-SEM, created in 2015 by Riegle, Wende and Will [39]. and implemented with SMART PLS tech. PLS -SEM is used to approximate dynamic representations of latent variables and their relations

[40]. The parameters of a structural equation model are calculated by applying the key variable analysis to regression path analysis. PLS is particularly useful for very particular study endeavours that involve small participants and biased distributions.

There are two sub models in the PLS analysis: measurement and structural model. The model calculates the relations between the data and the latent variables. The latent variables are all connected. The latent variables are related in the structural model. The structural equation model is solved by an iterative method by calculating latent variables using the measurement and the structural model in alternating stages, thus the name of the mechanism, partially. The structural model tests latent variables by regression with calculated latent variables in the measuring model. This algorithm is called convergence (Hair, 2019).

\section{DATA ANALYSIS}

\subsection{Data collecting and sample characteristics}

The data was taken within two weeks and received 118 respondents which means $78.6 \%$ response rate. After being checked for its validity and reliability, the questionnaires were valid and reliable with Cronbach's Alpha of 0.908. The demographic data in this study are age, gender, education level, position and working duration. The frequency of each character is shown in the table below: 


\begin{tabular}{|c|c|c|}
\hline Variables & No of Respondents & Percentage (\%) \\
\hline \multicolumn{3}{|l|}{ Age } \\
\hline $19-29$ years & 25 & 21.2 \\
\hline $30-39$ years & 38 & 32.2 \\
\hline $40-49$ years & 37 & 31.4 \\
\hline$\geq 50$ years & 18 & 15.3 \\
\hline \multicolumn{3}{|l|}{ Gender } \\
\hline Male & 99 & 83.9 \\
\hline Female & 19 & 16.1 \\
\hline \multicolumn{3}{|l|}{ Education } \\
\hline High school & 15 & 12.7 \\
\hline Diploma & 8 & 6.8 \\
\hline Bachelor & 95 & 80.5 \\
\hline \multicolumn{3}{|l|}{ Position } \\
\hline Controller & 3 & 2.5 \\
\hline Director & 5 & 4.2 \\
\hline Finance & 3 & 2.5 \\
\hline Head of Operation & 15 & 12.7 \\
\hline Manager & 37 & 31.4 \\
\hline Staff & 29 & 24.6 \\
\hline Supervisor & 26 & 22.0 \\
\hline \multicolumn{3}{|l|}{ Working duration } \\
\hline$<1$ years & 1 & 0.8 \\
\hline $1-5$ years & 55 & 46.6 \\
\hline $6-10$ years & 26 & 22.0 \\
\hline$>10$ years & 36 & 30.5 \\
\hline
\end{tabular}

Table 1 Demographics data

All of 118 respondents filled and completed the questionnaire. There were more males $(83.6 \%)$ than females $(16.1 \%)$ and most of them were in $30-39$ years old $(32.2 \%)$. Most of the respondent education background coming from bachelor (80.5\%), high school graduate $(12.7 \%)$, and diploma degree $(6.5 \%)$. Most of the respondents' positions are managers $(31.4 \%)$ and staff $(24.6 \%)$ with working duration range $1-5$ years $(46.6 \%)$.

\subsection{Measurement Model}

Evaluation of the measurement model serves to ascertain whether the indicators used in measuring latent variables are reliable and valid.

\subsubsection{Validity Test}

There are several indicators which values are $<0.7$, then it must be reduced from the model. Furthermore, a re-estimation is made on the model after being reduced to produce a valid indicator. Eleven items were carefully dropped, consisted of two items from customer loyalty, two items from customer satisfaction, and seven items from service quality. None of the indicators were dropped from the brand image variables. Figure 2 shows the results of the structural model with a standardized factor loading value on the model resulting from the reduction invalid indicators. Standardization factor loading for each indicator is greater than 0.7. This means that the indicators in the model are valid as a measurement tool for latent variables so that they can be used for modelling.

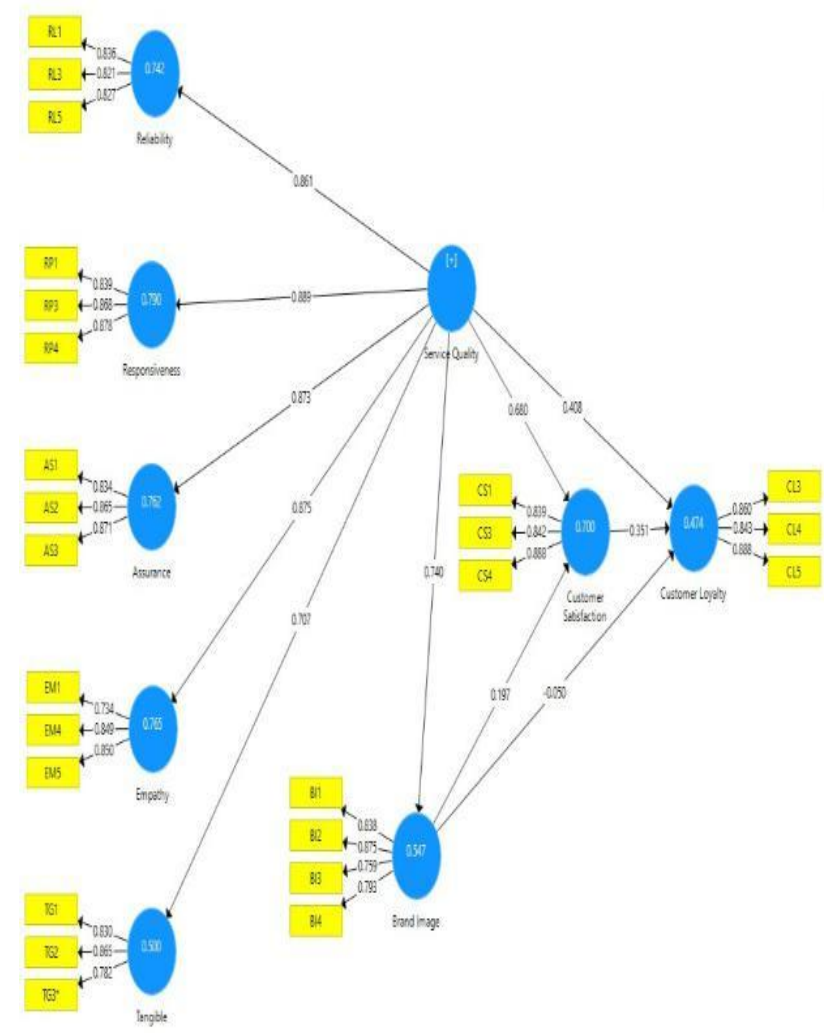

Figure 2 Standardized Loading Factor after selection

Then, we evaluate the AVE to addresses the convergent validity of each construct measure. Average variance extracted (AVE) value describe the amount of variance that can be explained by the question items (indicators) compared to the variance caused by measurement errors [41]. If the AVE value is above 0.5, it can be said that the latent variable has a good convergent validity. This means that latent variables can explain an average of more than half the variance of the indicators. The average variance extracted has often been used to assess discriminant validity based on the following rules: Based on the corrected correlations from the model, the AVE of each of the latent constructs should be higher than the highest squared correlation with any other latent variable. If that is the case, discriminant validity is established on the construct level [41]. Tables 2 shows the result of AVE value. 


\begin{tabular}{l|c|}
\hline Latent Variables & $\begin{array}{c}\text { Average Variance } \\
\text { Extracted (AVE) }\end{array}$ \\
\hline Assurance & 0.734 \\
\hline Brand Image & 0.668 \\
\hline Customer Loyalty & 0,746 \\
\hline Customer Satisfaction & 0.734 \\
\hline Empathy & 0.661 \\
\hline Reliability & 0.685 \\
\hline Responsiveness & 0.743 \\
\hline Tangible & 0,683 \\
\hline
\end{tabular}

Table 2 AVE value in each latent variable

Based on Table 2, the AVE values for all the variables are already greater than 0.5 . This means that the latent variable already has a good convergent validity where the latent variable can explain an average of more than half the variance of the indicators.

After we did convergent validity, the next step for validity test was discriminant validity. Discriminant validity is related to the principle that different construct gauges should not be highly correlated, so the discriminant validity of the reflexive measurement model can be calculated based on the Fornell Larcker and the cross-loading value of the manifest variable to each latent variable. Fornell Larcker is the correlation value between variables with the variable itself and variables with other variables. Good discriminant validity on Fornell Larcker is assessed by the correlation of the variable with the variable itself having to be higher than the other variables. Table 3 shows that the model has good discriminant.

The cross- loading size is to compare the association between the constructs and their structures and other blocks. Good discriminant validity may describe higher variables relative to variants of other constructs indicator. Table 3 indicates that each indicator has a detailed discriminating validity value and demonstrates that each indicator loading factor has a greater association than all other factors with the predictor, indicating that the positioning of an indicator in any dimension or variable is deemed correct.

\begin{tabular}{|l|l|l|l|l|l|l|l|l|}
\hline & AS & BI & CL & CS & EM & RL & RP & TG \\
\hline AS & 0.857 & & & & & & & \\
\hline BI & 0.697 & 0.817 & & & & & & \\
\hline CL & 0.460 & 0.498 & 0.864 & & & & & \\
\hline CS & 0.661 & 0.700 & 0.653 & 0.857 & & & & \\
\hline EM & 0.731 & 0.558 & 0.574 & 0.686 & 0.813 & & & \\
\hline RL & 0.692 & 0.636 & 0.631 & 0.753 & 0.696 & 0.828 & & \\
\hline
\end{tabular}

\begin{tabular}{|l|l|l|l|l|l|l|l|l|}
\hline RP & 0.730 & 0.642 & 0.524 & 0.761 & 0.743 & 0.698 & 0.862 & \\
\hline TG & 0.493 & 0.579 & 0.625 & 0.613 & 0.508 & 0.528 & 0.532 & 0.826 \\
\hline
\end{tabular}

Table 3 Fornell Larcker Result

\subsubsection{Reliability Test}

Reliability Test uses the Composite Reliability value whose value must be more than 0.7 . If the composite reliability value of each latent variable is greater than 0.70 , it indicates that the indicators have consistency in measuring their respective latent variables [42]. The composite reliability values are presented in table 4 and based on the table results show that all composite reliability values of all latent variables are more than 0,7 . So that it can be stated that all latent variables are enough reliable or in other words indicators have consistency in measuring their respective latent variables.

\begin{tabular}{|l|c|}
\hline & Composite Reliability \\
\hline Assurance & 0.892 \\
\hline Brand Image & 0.889 \\
\hline Customer Loyalty & 0.898 \\
\hline Customer Satisfaction & 0.892 \\
\hline Empathy & 0.853 \\
\hline Reliability & 0.867 \\
\hline Responsiveness & 0.897 \\
\hline Service Quality & 0.937 \\
\hline Tangible & 0.866 \\
\hline
\end{tabular}

Table 4 Composite Reliability 


\subsection{Structural Model}

Bootstrapping was used to produce T-statistics to assess the PLS-SEM model at the 95\% and 90\% significance level. Customer loyalty was the dependent variable and the three variables consisting of service quality, brand image and customer satisfaction. The results of this analysis are summarized in Table 5 and Table 6. To evaluate the structural model, this research used a determinant coefficient (R2 test). R-squared (R2) is used to calculate the effect of such independent latent variables on the dependency variable [43].

\begin{tabular}{|l|c|c|}
\hline Latent Variable & R Square & $\begin{array}{l}\text { R Square } \\
\text { Adjusted }\end{array}$ \\
\hline $\begin{array}{l}\text { customer } \\
\text { satisfaction }\end{array}$ & 0.547 & \\
\hline $\begin{array}{l}\text { customer loyalty } \\
\text { brand image }\end{array}$ & 0.474 & 0.543 \\
\hline
\end{tabular}

Table 5 Composite Reliability

\begin{tabular}{|c|c|c|c|c|c|}
\hline $\begin{array}{l}\text { Relations } \\
\text { of Latent } \\
\text { Variables }\end{array}$ & $\begin{array}{c}\text { Origina } \\
\mathbf{l} \\
\text { Sample }\end{array}$ & $\begin{array}{c}\text { Standar } \\
\text { d } \\
\text { Deviatio } \\
\text { n }\end{array}$ & $\begin{array}{c}\text { t- } \\
\text { value } \\
\text { s }\end{array}$ & $\begin{array}{c}\text { p- } \\
\text { values }\end{array}$ & $\begin{array}{c}\text { Hypothesi } \\
\text { s Test } \\
\text { Result }\end{array}$ \\
\hline $\begin{array}{l}\text { brand } \\
\text { image -> } \\
\text { customer } \\
\text { satisfactio } \\
\text { n }\end{array}$ & 0.197 & 0.103 & $\begin{array}{c}1.91 \\
5\end{array}$ & $\begin{array}{c}0.056 \\
* *\end{array}$ & Accepted \\
\hline $\begin{array}{l}\text { service } \\
\text { quality -> } \\
\text { customer } \\
\text { satisfactio } \\
\text { n }\end{array}$ & 0.680 & 0.091 & $\begin{array}{c}7.44 \\
3\end{array}$ & $\begin{array}{c}0.000 \\
*\end{array}$ & Accepted \\
\hline $\begin{array}{l}\text { customer } \\
\text { satisfactio } \\
\mathrm{n}-> \\
\text { customer } \\
\text { loyalty }\end{array}$ & 0.351 & 0.128 & $\begin{array}{c}2.74 \\
8\end{array}$ & $\begin{array}{c}0.006 \\
*\end{array}$ & Accepted \\
\hline $\begin{array}{l}\text { service } \\
\text { quality -> } \\
\text { customer } \\
\text { loyalty }\end{array}$ & 0.408 & 0.144 & $\begin{array}{c}2.83 \\
6\end{array}$ & $\begin{array}{c}0.005 \\
*\end{array}$ & Accepted \\
\hline $\begin{array}{l}\text { brand } \\
\text { image -> }\end{array}$ & & & & & Rejected \\
\hline
\end{tabular}

\begin{tabular}{|c|c|c|c|c|c|}
\hline $\begin{array}{l}\text { customer } \\
\text { loyalty }\end{array}$ & -0.050 & 0.105 & $\begin{array}{c}0.47 \\
5\end{array}$ & 0.635 & \\
\hline $\begin{array}{l}\text { service } \\
\text { quality -> } \\
\text { brand } \\
\text { image }\end{array}$ & 0.740 & 0.047 & $\begin{array}{c}15.8 \\
50\end{array}$ & $\begin{array}{c}0.000 \\
*\end{array}$ & Accepted \\
\hline $\begin{array}{l}\text { service } \\
\text { quality -> } \\
\text { customer } \\
\text { satisfactio } \\
\text { n -> } \\
\text { customer }\end{array}$ & 0.239 & 0.09 & $\begin{array}{c}2.65 \\
3\end{array}$ & $\begin{array}{c}0.008 \\
*\end{array}$ & Accepted \\
\hline loyalty & & & & & \\
\hline $\begin{array}{l}\text { brand } \\
\text { image -> } \\
\text { customer } \\
\text { satisfactio } \\
\mathrm{n} \text {-> } \\
\text { customer } \\
\text { loyalty }\end{array}$ & 0.069 & 0.05 & $\begin{array}{c}1.37 \\
5\end{array}$ & 0.17 & Rejected \\
\hline
\end{tabular}

Table 6 Direct and Indirect Effect

Furthermore, the total value of R2 is used to calculate Predictive Relevance (Q2). The Q2 value is used to validate the model. If the $\mathrm{Q} 2$ value is greater than 0.5 indicates that the model has a good Predictive Relevance. The Predictive Relevance (Q2) value can be written as follows:

$$
\begin{aligned}
& 2=1-\{(1-\quad 1)(1-\quad 2)\} \\
= & 1-\{(1-0.547)(1-0.474)(1-0.700)\}=0.928
\end{aligned}
$$

From the above calculation, the value of $\mathrm{Q} 2=0.928$ is greater than 0.5 , it means that the model in this study has a good predictive relevance. 


\subsection{IPMA}

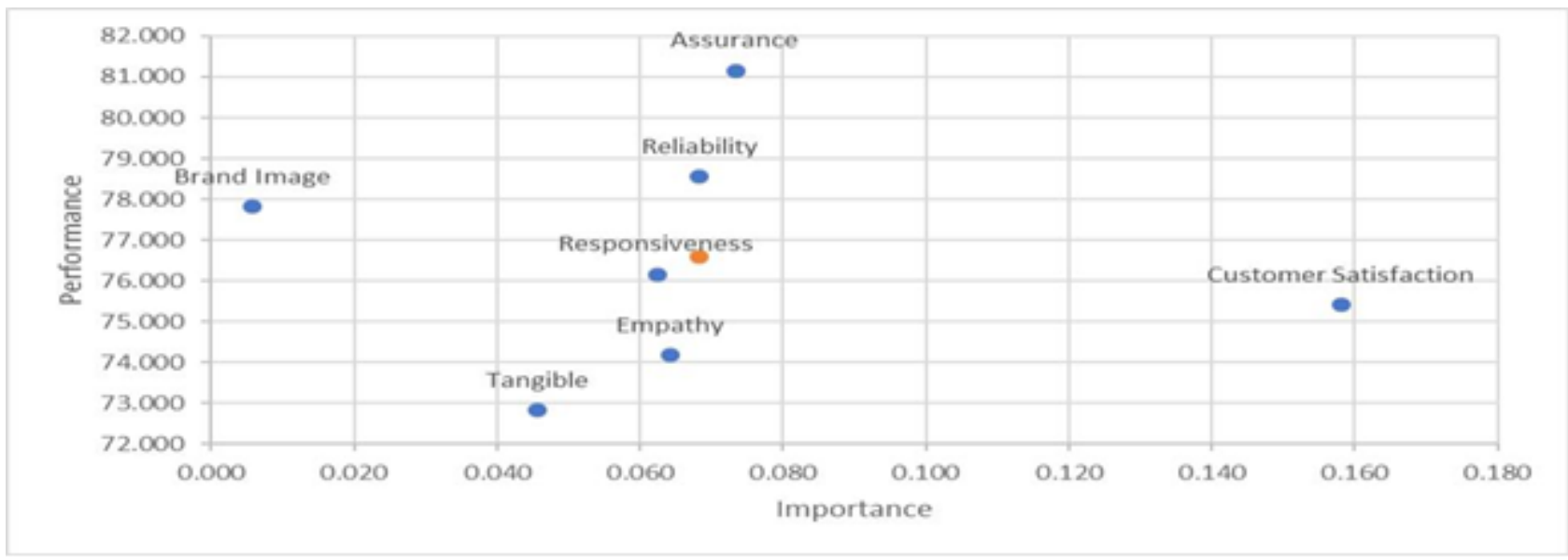

Figure 3 IPMA for Customer Loyalty

PLS -SEM tests provide information on how the different constructs in the model affect the overall model. It encourages further discussion of the findings by expanding the study of the cumulative effects in the model by introducing a second level for the results analysis that involves the average latent variables values

[44]. The IPMA extended-statistical covariance structure analysis extends the results of PLS-SEM by taking performance into account. As shown on Table 5 the findings of total effects (importance) and indexvalues (performance) and the Figure 3 shows the scatter chart of the priority map.

\begin{tabular}{lcr}
\hline \multicolumn{1}{c}{$\begin{array}{c}\text { Latent } \\
\text { Constructs }\end{array}$} & $\begin{array}{c}\text { Total Effect of } \\
\text { the construct } \\
\text { performance } \\
\text { impact } \\
\text { (importance) }\end{array}$ & $\begin{array}{c}\text { Index values } \\
\text { (performance) }\end{array}$ \\
\hline Assurance & 0.073 & 81.147 \\
\hline Brand Image & 0.006 & 77.818 \\
\hline Customer & 0.158 & 75.410 \\
Satisfaction & 0.064 & 74.180 \\
\hline Empathy & 0.068 & 78.552 \\
\hline Reliability & 0.062 & 76.161 \\
\hline Responsiveness & 0.046 & 72.814
\end{tabular}

Table 7 IPMA Performance Impact importance is the customer satisfaction. It means that managerial should focus more on customer satisfaction rather than the brand. For the service quality aspect, which was divided into five dimensions in this research, tangibles have the lowest importance and performance which means that it is the low priority of this sector. While for empathy and responsiveness, these are the aspects that the managerial should consider about to increase the level of performance. For reliability and assurance, as the positions are on the right of the orange dots, it means that the managerial should keep up the good work of these aspects.

\subsection{Goodness-of-Fit (GoF)}

Even though, PLS-SEM do not produce a GoF index, R2 still demonstrates the model's explanatory capacity [45]. As presented by Tenenhaus [46], the GoF is determined using the geometric mean of communality score and econometric projections of residuals for endogenous component with the following equation $\mathrm{GoF}=\sqrt{ }(\mathrm{AVE} \times \mathrm{R} 2)$. Wetzels [47] used the following cutoff values to recommend the fitness of an analysis: $\quad$ GoFsmall $=0.1$; GoFmedium $=0.25$; GoFlarge $=0.36$. Thus, the result of the GoF of this research is as follows:

\begin{tabular}{|l|c|c|}
\hline \multicolumn{1}{|c|}{ Latent Variables } & $\begin{array}{c}\text { Average Variance } \\
\text { Extracted (AVE) }\end{array}$ & R Square \\
\hline brand image & 0.668 & 0.547 \\
\hline customer loyalty & 0.734 & 0.474 \\
\hline customer satisfaction & 0.746 & 0.7 \\
\hline
\end{tabular}

Based on the data, the least importance aspect of air cargo is brand image. The highest 


\begin{tabular}{|l|ll|l|}
\hline mean & 0.716 & 0.574 \\
\hline GoF & \multicolumn{3}{|c|}{$\mathbf{0 . 6 4 1}$} \\
\hline
\end{tabular}

Table 8 Goodness of Fit

The conceptual model described in the study yielded a "good" GoF index value of 0.641 , indicating an excellent fit of the model.

\section{DISCUSSION}

\subsection{Conclusion and Implications}

Provided that customer loyalty is one of the primary priorities of businesses that aim to maintain long-term viability and longevity, transport companies need to develop proactive strategies to maximize customer saturation and practices that can boost any aspect of the quality of services [5]. While the satisfaction of consumers and the standard of service is a well-established record of consumer loyalty, there are very few reports on the brand reputation and customer loyalty in air cargo industry especially during the pandemic situation. The convergence of user satisfaction and image into one paradigm not only stresses the importance of image, but also highlights customer engagement further.

This research reveals that both image and customer satisfaction can be used to measure customer loyalty. The report is one of the first to empirically examine the impacts on consumer satisfaction, brand image and customer loyalty of service quality in a single air freight climate sample. The detailed service quality model, which demonstrates the relations between measures and other similar constructs, provides a systematic methodology for conceptually and empirically defining the quality and basic aspects of service. It enables global satisfaction evaluation after service level appraisal [29]. The other key result was that loyalty was indirectly influenced by service quality and consumer satisfaction. Brand image is not considered as the key priority for customer when they want to create a cooperation or conduct transactions related to their cargo shipping. The management should focus more on the aspect of responsiveness and empathy to enhance the customer satisfaction by increasing the performance index values. It was related to some aspects about security aspect of the cargo and the response of the customer care who deal with customer directly. The customer also wants to have more informative platform to monitor the movement of their cargo in real time data.

\subsection{Limitations and Recommendations}

This study has certain limitations, given these findings. Firstly, owing to practical limitations, a convenience sampling technique was employed. In order to better understand the freight industry and verify these results by using a randomized survey, a larger sample or replication of this research in a different community of subjects will examine the essential interaction between structures. Secondly, depending on the expertise of the air freight sector, the dimensions used for assessing service quality variables could be altered. Third, the various types of image impact can be examined in order to look at the different theorems further. Lastly, this research on the variable brand image, customer satisfaction and customer loyalty are only limited to one dimension, then in further research, it can be further examined about the dimensions associated with these variables.

\section{AUTHORS' CONTRIBUTIONS}

Both Authors contributed equally in creating the research design, analyzing data and writing the paper. Author 1 makes substantial contributions in data collection.

\section{ACKNOWLEDGMENTS}

The Author expresses sincere appreciation to all those who contributed to this research and the writing of this research paper.

\section{REFERENCES}

[1] Li, T. (2020). A SWOT analysis of China's air cargo sector in the cont ext of COVID-19 pandemic. Journal of Air Transport Management, 88(August), $101875 . \quad$ DOI: https://doi.org/10.1016/ j.jairtraman.2020.101875

[2] The Jakarta Post. Consumers drawn to home products, free shipping during pandemic. https://www.thejakartapost.com/paper/2020/11/01/ consumers-drawn-to-home-products-free-shippingduring-pandemic.html.

[3] C. Baier, J-P. Katoen, Principles of Model Checking, MIT Press, 2008.

[4] Griffin, J. (2002). Customer loyalty: How to earn it, how to keep it (p. 18). San Francisco, CA: Jossey-Bass. 
[5] Gil-saura, I., Berenguer-contri, G., \& Ruiz-molina, M. E. (2018). Satisfaction and Loyalty in B2B Relationships in the Freight Forwarding Industry: Adding Perceived Value and Service Quality into Equation. Transport, 33(5), 1184-1195. DOI: https://doi.org/10.3846/transport.2018.6648

[6] Hu, K. C., \& Huang, M. C. (2011). Effects of service quality, innovation and corporate image on customer's satisfaction and loyalty of air cargo terminal. International Journal of Operations Research, 8(4), 36-47.

[7] Hu, Y., Lee, P.-C., Chuang, Y.-S., \& Chiu, Y.-J. (2018). Improving the Sustainable Competitiveness of Service Quality within Air Cargo Terminals. Sustainability (Switzerland), 10(2319). DOI: https://doi.org/10.3390/su10072319

[8] Tsai, M. C., Merkert, R., \& Wang, J. F. (2020). What drives freight transportation customer loyalty? Diverging marketing approaches for the air freight express industry. Transportation, 0123456789. DOI: https://doi.org/10.1007/s11116020-10104-0

[9] Davis, B. R., \& Mentzer, J. T. (2006). Logistics service driven loyalty: an exploratory study. Journal of Business Logistics, 27(2), 53-73. DOI: https://doi.org/10.1002/j.21581592.2006.tb00217.x

[10] Bardauskaite, I. (2014). Loyalty in the Business-toBusiness Service Context: A Literature Review and Proposed Framework Loyalty in the Businessto-Business Service Context: A Literature Review and Proposed. Journal of Relationship Marketing, 13(1), 28-69. DOI:

https://doi.org/10.1080/15332667.2014.882628

[11] Chang, C., \& Thai, V. V. (2016). Do port security quality and service quality influence customer satisfaction and loyalty? Maritime Policy \& Management, 8839(March), 1-17. DOI: https://doi.org/10.1080/03088839.2016.1151086

[12] Anderson, E. W., Fornell, C., \& Lehmann, D. R. (1994). Customer Satisfaction, Market Share, and Profitability: Findings from Sweden. Journal of Marketing, 58(3), 53. DOI: https://doi.org/10.2307/1252310

[13] Tsoukatos, E., \& Rand, G. K. (2006). Path analysis of perceived service quality, satisfaction and loyalty in Greek insurance. Managing Service
Quality, $\quad 16(5), \quad 501-519 . \quad$ DOI: https://doi.org/10.1108/09604520610686746

[14] Reinartz, W., \& Kumar, V. I. S. W. A. N. A. T. H. A. N. (2002). The mismanagement of customer loyalty. Harvard business review, 80(7), 86-94.

[15] Maintaining customer loyalty during uncertainty: Deloitte. (2020, March 24). Retrieved January 15, 2021, from https://www2.deloitte.com/gr/en/pages/ about-deloitte/articles/maintaining-customerloyalty-during-uncertainty.html

[16] Ennew, C. T., Reed, G. V., \& Binks, M. R. (1993). Importance-performance analysis and the measurement of service quality. European journal of marketing, 27(2), 59-70. DOI: https://doi.org/10.1108/03090569310026402

[17] Parasuraman, A., Berry, L. L., \& Zeithaml, V. A. (1991). Refinement and reassessment of the SERVQUAL scale. Journal of Retailing, 67(4), $420 . \quad$ Retrieved from https://search.proquest.com/scholarlyjournals/refin ement-reassessment-servqualscale/docview/228675435/se-2?accountid=17242

[18] Berry, L. L. (2000). Cultivating service brand equity. Journal of the Academy of Marketing Science, 28(1), 128-137. DOI: https://doi.org/10.1177/0092070300281012

[19] Wijaya, B. S. (2009). Development Model of Marketing Capabilities and Export Performance of SMEs: A Proposed Study. European Journal of Business and Management, 10(22), 107-114. DOI: https://doi.org/10.13140/ejbm.2013.55.65

[20] Fournier, S. (1998). Consumers and Their Brands Developing. Journal of Consumer Research, 24(4), 343-353.

[21] Nuseir, M. T., \& Madanat, H. (2015). 4Ps: A strategy to secure customers' loyalty via customer satisfaction. International Journal of Marketing Studies, 7(4), 78. DOI: 10.5539/ijms.v7n4p78

[22] Gerpott, T. J., Rams, W., \& Schindler, A. (2001). Customer retention, loyalty, and satisfaction in the German mobile cellular telecommunications market. Telecommunications Policy, 25(4), 249 $269 . \quad$ https://doi.org/10.1016/S03085961(00)00097-5

[23] Levesque, T., \& McDougall, G. H. (1996). Determinants of customer satisfaction in retail banking. International journal of bank marketing. DOI: https://doi.org/10.1108/02652329610151340 
[24] Reichheld, F. F., \& W. Earl Sasser, J. (1990). Zero Defections: Quality Comes to Services. Harvard Business Review, 68(5), 105-111.

[25] Mcilroy, A., \& Barnett, S. (2000). Building customer relationships: Do discount cards work? Managing Service Quality: An International Journal, 10(6), 347-355. DOI: https://doi.org/10.1108/09604520010351491

[26] Oliver, R. L. (1999). Whence consumer loyalty?. Journal of marketing, 63(4_suppl1), 33-44. DOI: https:// doi.org/10.1177/00222429990634s105

[27] Liat, C. B., Mansori, S., \& Huei, C. T. (2014). The Associations Between Service Quality, Corporate Image, Customer Satisfaction, and Loyalty: Evidence From the Malaysian Hotel Industry. Journal of Hospitality Marketing \& Management, 23(3), 314-326. DOI: https:// doi.org/10.1080/19368623.2013.796867

[28] Farquhar, P. H. (1989). Managing Brand Equity. Marketing Resesearch, 1(September), 24-33.

[29] Lee, H., Lee, Y., \& Yoo, D. (2000). The determinants of perceived service quality and its relationship with satisfaction. Journal of Services

Marketing, 14(3), 217-231. DOI: https://doi.org/10.1108/08876040010327220

[30] Mathong, P., Sureeyatanapas, P., Arunyanart, S., \& Niyamosoth, T. (2020). The assessment of service quality for third-party logistics providers in the beverage industry. Cogent Engineering, 7(1), 1785214. DOI: ttps:// doi.org/10.1080/23311916.2020.1785214

[31] Tu, Y.-T., Wang, C.-M., \& Chang, H.-C. (2012). Corporate Brand Image and Customer Satisfaction on Loyalty: An Empirical Study of Starbucks Coffee in Taiwan. Journal of Social and Development Sciences, 3(1), 24-32.

DOI: https://doi.org/10.22610/jsds.v3i1.682

[32] Juga, J., Juntunen, J., \& Juntunen, M. (2012). Impact of service quality, image and relational aspects on satisfaction and loyalty in logistics outsourcing relationships. International Journal Shipping and Transport Logistics, 4(1), 17-28.

[33] Anselmsson, J., Bondesson, N. V., \& Johansson, U. (2014). Brand image and customers' willingness to pay a price premium for food brands. Journal of Product \& Brand Management. DOI: https://doi.org/10.1108/JPBM-10-2013-0414
[34] Etikan, I., Musa, S. A., \& Alkassim, R. S. (2016). Comparison of Convenience Sampling and Purposive Sampling Comparison of Convenience Sampling and Purposive Sampling. American Journal of Theoretical and Applied Statistics, 5(1), 1-4. DOI: https://doi.org/10.11648/j.ajtas.20160501.11

[35] Bernard, J. M. (1979). Supervisor training: A discrimination model. Counselor Education and Supervision, 19(1), 60-68. DOI: https://doi.org/10.1002/j.1556-6978.1979.tb00906.x

[36] Farlow, C. A., Chenault, D. B., Pezzaniti, J. L., Spradley, K. D., \& Gulley, M. G. (2002, January). Imaging polarimeter development and applications. In Polarization Analysis and Measurement IV (Vol. 4481, pp. 118-125). International Society for Optics and Photonics. DOI: https://doi.org/10.1117/12.452880

[37] Slovin, E. (1960). Slovin's formula for sampling technique. Retrieved on February, 13, 2013.

[38] Wong, K. K.-K. (2013). Partial Least Squares Structural Equation Modeling (PLS-SEM) Techniques Using SmartPLS. Marketing Bulletin, 24(1), 1-32. http:// marketing -

bulletin.massey.ac.nz/v24/mb_v24_t1_wong.p

df\%5Cnhttp://www.researchgate.net/profile/

Ken_Wong10/publication/268449353_Partial_Least_Sq uares_Structural_Equation__ Modeling_(PLSSEM)_Techniques_Using_SmartPLS/ links/54773b1b0cf293e2da25e3f3.pdf

[39] Sarstedt, M., Ringle, C. M., \& Hair, J. F. (2020). Handbook of Market Research. In Handbook of Market Research (Issue September). DOI: https://doi.org/10.1007/978-3-319-05542-8

[40] Fornell, C., \& Larcker, D. F. (1981). Structural equation models with unobservable variables and measurement error: Algebra and statistics.

[41] Hair Jr, J. F., Sarstedt, M., Ringle, C. M., \& Gudergan, S. P. (2017). Advanced issues in partial least squares structural equation modeling. saGe publications.

[42] Ghozali, I. (2012). Imam Ghozali. 2012. Aplikasi analisis multivariate dengan program ibm spss, 20.

[43] Ringle, C. M., \& Sarstedt, M. (2016). Gain more insight from your PLS-SEM results. Industrial Management \& Data Systems. 
[44] Henseler, J., Hubona, G., \& Ray, P. A. (2016). Using PLS path modeling in new technology research: updated guidelines. Industrial management \& data systems.

[45] Tenenhaus, M., Vinzi, V. E., Chatelin, Y. M., \& Lauro, C. (2005). PLS path modeling. Computational statistics \& data analysis, 48(1), 159-205.

[46] Wetzels, M., Odekerken-Schröder, G., \& Van Oppen, C. (2009). Using PLS path modeling for assessing hierarchical construct models: Guidelines and empirical illustration. MIS quarterly, 177-195. 